\title{
Artists, Cultural Gentrification and Public Policy
}

\author{
Antònia Casellas, Esteve Dot-Jutgla and Montserrat Pallares-Barbera \\ Antònia Casellas, Department of Geography, Universitat Autònoma de Barcelona, Barcelona, Spain \\ (antonia.casellas.@uab.cat)
}

Esteve Dot-Jutgla, Department of Geography, Universitat Autònoma de Barcelona, Barcelona, Spain (esteve.dot@uab.cat)

Montserrat Pallares-Barbera, Department of Geography, Universitat Autònoma de Barcelona, Barcelona, Spain (montserrat.pallares@uab.cat)

\begin{abstract}
Since the 1980s, artists have been studied as agents of urban gentrification. Well established theories and case studies have provided numerous evidences of the role of artists as initiators of the gentrification process in working-class neighborhoods. From a productive-side perspective, placing an emphasis on the rent-gap and land development, as well as consumption-side perspective, analyzing the features of individuals, art production and artists have been identified as a source of initial gentrification. Complementary theorizations have studied the second wave of displacement produced by the massive arrival of private capital, which often has affected the artists themselves. The present paper adds to the body of literature than identifies the public sector as another key agent of gentrification. The paper analyzes the role of Barcelona's public sector in the process of implementing this redevelopment program, and its interaction with artists in the neighborhood. In specific terms, it discusses the case of the Hangar Collective, located in Can Ricart, an old factory building which had been the home of small firms and artist groups. This center was at the heart of the urban struggle to maintain the status of firms and artists in the neighborhood, and to preserve the architectonic structure of the old factory complex. By 2010, once displaced small firms and groups of low-budget artists, only the artist's association with Hangar, supported by public funds, remained in Can Ricart.
\end{abstract}

Keywords: public policy, gentrification, artist, new economy, Barcelona

\section{Introduction}

In the year 2000, with the aim of positioning Barcelona as a key centre in the Mediterranean region while simultaneously expanding its urban and socio-economic base, the Barcelona City Council began an ambitious process of radical urban transformation in the central working class neighbourhood of Poblenou (New Town in Catalan). The project aims to transform 200 hectares into a new technological platform, to boost both the city and Catalonia in the international arena. The ultimate goal is for the area to specialize in the knowledge-rich activities that are forecast to be the engines of the new urban economy created by the technological revolution. This paper analyzes the role of Barcelona's public sector in the process of implementing this redevelopment programme, and its interaction with artists in the neighbourhood. In specific terms, we discuss the case of the Hangar Collective, located in Can Ricart, an old factory building which is the home of small firms and artist groups. This centre was at the heart of the urban struggle to maintain the status of firms and artists in the neighbourhood and to preserve the structure of the old factory complex, Can Ricart, where they were located. In late 2009, only the artist's association, Hangar, remained in Can Ricart. 
From the production perspective, with an emphasis on the rent-gap and land development, the literature has identified art production and artists as a source of gentrification of a decaying area within the city (Smith 1986, 1987, 1996). From the perspective of consumption, the characteristics of artists' lifestyles and 'bohemia', have been discussed as a potential factor in attracting investment, as the characteristics of bohemia contributes to the gentrification of decayed urban centres (Lloyd 2006, Zukin 1982, Tironi 2009, Martí-Costa and Bonet-Martí 2008).

Before the urban redevelopment plan, Poblenou had a precarious infrastructure which made the area unattractive to both new residents and economic activities. By the end of the 1990s, the design of a new redevelopment plan in Poblenou created large amounts of very well-connected space; in close proximity to a planned new high-speed railway station, the city centre and Barcelona International Airport.

Some artists had arrived in Poblenou since the 1980s; this was because it was the poorer area neighbouring El Raval and El Born, two of the neighbourhoods in central Barcelona, which began a process of gentrification at the end of the twentieth century. Poblenou offered spaces suitable for artists in old industry buildings. The beginning of an artistic process of location thereby started and was eventually aborted by the new urban renewal plan implemented under public sector leadership. The result was that a critical mass of artists located in the area was not created because the existing artists' workshops in the area were dispersed and few in number. Nevertheless, an informal meeting of artists and residents led to a response to the urban plan proposed by the City Council. The new urban plan included new zoning regulations and a top-down economic redevelopment strategy, which generated high expectations among landowners and real estate developers. This public intervention also implied a gradual increase in the cost of land, which increased housing rents and forced out some of the artists previously located in the neighbourhood.

This paper is organized as follows. The following section discusses the key issues in the literature about artists and urban gentrification. The subsequent section considers the leading role of the public sector in the redevelopment of Poblenou and presents the main features of the 22@Barcelona Project. Finally, the fourth section introduces the specific case of the Hangar Collective group of artists, which managed to survive in the new 22@Barcelona neighbourhood with institutional support; concluding remarks follow at the end of the paper.

\section{Current State of the Art Vis-à-Vis Artists and Gentrification}

As a precondition in the gentrification process there must be a downtown area suffering from urban deterioration, which attracts low-income groups to live in the area; in a second period, higher income groups become interested in moving to these deteriorated areas because of their good and central location. A rent-gap-regeneration process then emerges, in which new investment starts to flow towards the deteriorated urban fabric; this creates a rent-gap between the ground rent of depressed land and the potential rent that could be capitalized from the highest and best use, given its central location (Smith 1986, 1987, 1996). Robert Beauregard (1986) has addressed the complexity of gentrification factors and referred to the characteristics of potential gentrifiers, the existence of gentrifiable housing with its potential higher economic value and the role of public policies in the gentrification process.

Devalued, deteriorated and inexpensive buildings are typical features of town centre environments. When these characteristics are combined with some potential 
architectonic value, it is possible for the value of the housing stock to be enhanced and attract the attention of possible investors. The gentrified group could thus be defined as the people living in inexpensive but architecturally desirable housing, who are economically and politically powerless. Meanwhile, the gentrifiers are the group wishing to invest in and move to the poorer area. The gentrification process itself is sometimes facilitated by public laws that vary by country and governing coalition.

At the same time, the individuals involved in the process are sometimes artists, who often become the initial agents of gentrification. Sharon Zukin (1982), in her seminal work on Lower East Manhattan, explored how in the 1970s artists relocated to the area due to the availability of numerous buildings that provided big spaces. This created a low-rent bohemian, low-income group of artists. The Lower East Side eventually became fashionable, and appealed to some segments of the middle class population. This brought about an increase in rents and property prices that eventually displaced the original low-income artists. Richard Lloyd (2006) reached similar conclusions in his study of an area northwest of the Chicago Loop. The area initially attracted artists thanks to the existence of cheap rents, abundant study space and its proximity to public transport. Nevertheless, the presence of these artists transformed the identity of the neighbourhood, which became fashionable due to a 'bohemia mythology' image and which acted as a real estate marketing strategy that attracted new residents that ultimately led to a gentrification of the neighbourhood. From a consumption perspective, David Ley $(1987,1994)$ introduced the importance of cultural values. These are mainly issues related to the ideology of the gentrifiers, their consumer and demand practices as well as the role of race, gender, education, occupational change and household composition. In the case of Shoreditch in Greater London, artists, initially squatting, began using empty factories at the end of the twentieth century. With time, the neighbourhood began to be attractive and eventually a thriving service sector with very high demand for residential and office accommodation took root (Hayward 2006).

In Europe, the phenomenon of city centre gentrification has also arisen in numerous former industrial cities and is mostly times linked with the active role played by the public sector, which has often promoted specific cultural and urban redevelopment policies in its efforts to transform old industrial areas inside the city (Bianchini and Parkinson 1993). These authors present a detailed study of cultural policy-making, which shows the interrelation of cultural development and urban regeneration in former industrial centres such as Glasgow, Hamburg and Bilbao, and academic and regional centres such as Bologna and Montpellier. The rationale of policy makers for using culture as a redevelopment strategy is based on the possibility of fostering local economic development while supporting the city's marketing strategies. This policy has been reinforced by activities in the new economy as a source of economic local development. As Krueger and Gibbs (2007) point out, new economy spaces are a new sphere of convergence between economic activity and culture. Because highly paid workers in the new economy appear to be especially interested in quality of life issues, the features of the urban space, of which culture is a key factor, become relevant.

Changes due to the labour market and local policies have highlighted the importance of professionalization (Atkinson 2000). In order to measure the loss of groups associated with displacement, Atkinson suggests the proxy indicator of professionalization as a potential causal mechanism in gentrification. In his work, he 
describes how certain areas of London have undergone a social evacuation effect as a result of the process of professionalization.

\section{The Barcelona Context: The Public Sector's Urban Renewal Projects}

Since the mid 1980s, in the context of the massive urban transformation linked to the 1992 Olympic Games, and under the leadership of the public sector, numerous neighbourhoods in Barcelona have undergone a process of dramatic transformation. Following the decision for Barcelona to bid to host the 1992 Olympics, the Mayor Pasqual Maragall proposed the creation of a new maritime district on its waterfront (Maragall 1988) in 1984. A newly redeveloped area was urbanized; with 50 hectares of parks, a small leisure harbour, a pedestrian seafront running along the beaches and a port, two 42 storey skyscrapers - a hotel and an office complex - and 1,854 homes and 220 commercial premises (Martorell et al. 1992). A portion of this redeveloped area was in the Poblenou area.

Poblenou used to be called the Catalan Manchester, when between the midnineteenth century and the early twentieth century, the new industrialization of Barcelona led to the relocation of its factories from the city centre to what were at the time the outskirts of the city. By the late 1980s, Poblenou was centrally located, with outdated and inadequate infrastructure, many decaying factories and an obsolete urban stock. Two railway lines ran along the coastline at ground level, separating the seafront from the city. Poblenou had lost population since the mid-1970s (Marrero-Guillamón 2000); but during the 1990s, unlike the rest of Barcelona, the population of Poblenou increased from 46,832 to 49,141 (from 1991 to 1998). This shift in the demographic pattern of Poblenou was due to the 1992 public project to develop the coastline, which as well as improving the coastline, creating a new maritime district and its waterfront, led to the construction of the Olympic Village to accommodate athletes during the Olympic Games. These buildings were subsequently sold to new residents of Barcelona.

After the Olympics, part of Poblenou's sea front was further redeveloped to host the Universal Forum of Cultures in 2004. This renewal program included two interlinked urban plans on the waterfront: the Universal Forum of Cultures and Diagonal Mar. The Universal Forum idea built upon Barcelona's success in revitalizing decaying neighbourhoods by hosting mega-events in the past, starting with the World Fairs of 1888 and 1929 (Casellas 2009), and later, the 1992 Olympic Games. The project to host the Universal Forum was the continuation of the redevelopment on the sea front, with the construction of new facilities and hotels in an area of 50 hectares.

At the same time as the Universal Forum project, in 2000, the City Council began the '22@Barcelona project', the most dramatic urban renewal of Barcelona in Poblenou (Figure 1). This time, the objective was to foster economic growth in the city linked to the attraction of high-tech and knowledge related activities. The plan approved involved a drastic urban and social transformation of the neighbourhood. The plan had a total potential roof space of 4 million square meters, of which 80 per cent was for productive activities and 20 per cent for other uses, including housing and facilities. Policymakers placed special emphasis on the possible new jobs generated by the project, which were estimated at 130,000 skilled jobs in 2000 . There was also a clear stress on the real estate potential of the project, which was estimated at 12,020 million $€$ (22@Barcelona, 2008). 


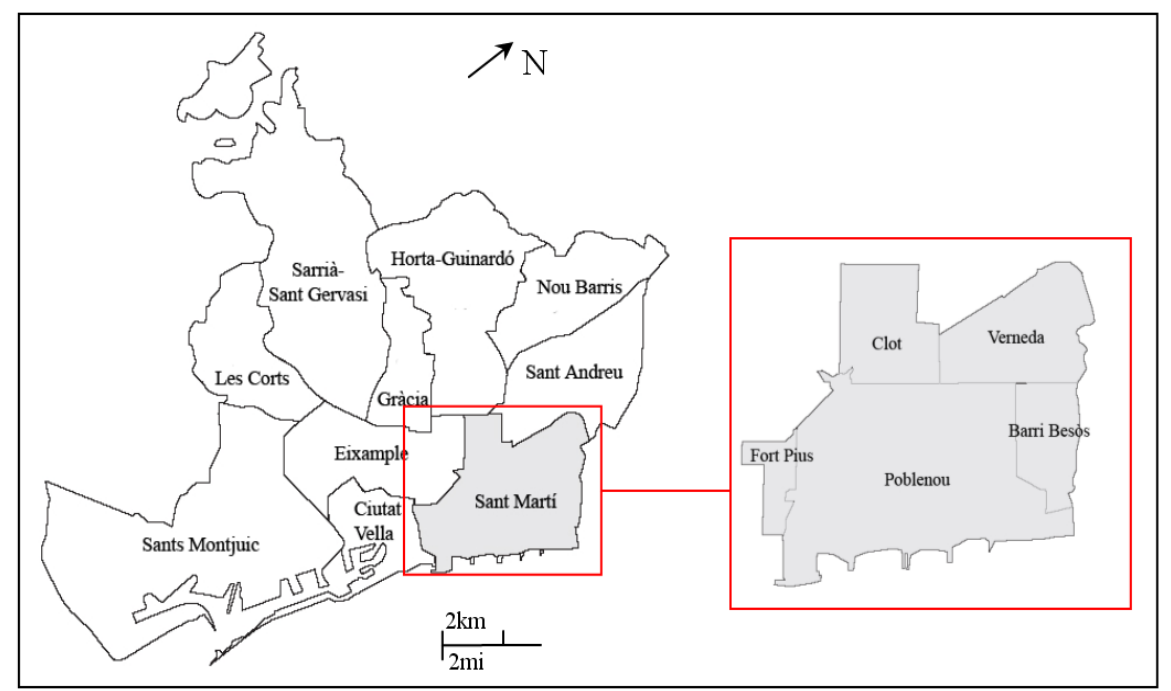

Figure 1: Location of Poblenou in the Sant Martí District (Barcelona).

Source: adapted from www.bcn.es (2008).

The name of the plan, '22@Barcelona' came from the rezoning of the industrial land labelled 22a in Barcelona's Metropolitan Master Plan of 1976 - the Pla General Metropolità (PGM) - and symbolizes the new economic cluster activities envisioned in the plan. It introduced the coexistence of diverse land uses in Poblenou: high-tech industries, housing, offices, commerce, hotels, amenities and green space to a previously zoned industrial land. The plan enumerated which activities were considered to be knowledge-related. It identified a broad range of activities, including those strictly related to information and communication technologies (ICT) but also included others: "those activities that use information as raw material and whose end product is knowledge” (Barcelona City Council 2000). They were presented in three subgroups: ICT, services and knowledge centres. Economic activities not included on the list were forbidden from the area due to the new zoning regulations. Considering the historically industrial character of the neighbourhood, the issue of industrial gentrification has been identified (Dot 2009). After only 9 years of implementation, by 2009, with more than 60 per cent of the targeted land transformed, the urban outcomes of the project were quite remarkable. Nevertheless, with regard to the economic transformation, methodological difficulties due to fuzziness in the classification of economic activities, a lack of accuracy in gathering data, and the statistical methodology used do not allow a clear assessment to be made (Casellas and Pallares-Barbera, 2009).

\section{Methodology}

The study area was Poblenou-22@Barcelona. In specific terms, we concentrated on the possible effects on the location of artistic activity in the early twenty-first century due to spatial and economic restructuring. The Hangar Collective artistic activity centre is considered a relevant point for analysis due to its location in the former textile space of Can Ricart and because of its pivotal role agglutinating all the social and neighbourhood-based demonstrations against the institutional development of the area. Methodologically, data has been drawn from information from various secondary sources as well as primary ones, such as in-depth interviews. We collected data from the 22@Barcelona website (www.22@bcn.com), as well as reports by the Association of Visual Artists of Catalonia (www.aavc.net). Analysis of local newspapers completed 
this initial documentation of the general transformation process in the neighbourhood. The data on the real estate market in Barcelona was taken from the Statistics Department of Barcelona (www.bcn.es/estadistica). This source enabled us to study the evolution of housing and commercial prices in the area between 1992 and 2007.

We also interviewed the managerial team of the artistic production centre of Hangar in two periods, in 2005 and in 2007. The aim of the interviews was to assess how the new urban and economic redevelopment affected the artists of Hangar.

\section{Artists on the Move: The Poblenou Experience}

Barcelona's nomination as an Olympic city implied significant improvements in infrastructures, communications, and an array of projects on a neighbourhood scale. Land prices in Barcelona increased dramatically between 1992 and 2007, especially in the city centre (the Ciutat Vella district). Numerous artists moved from their traditional locations in the centre of the city, such as the Born and Raval neighbourhoods, to alternative areas that were not as dramatically affected by the rising prices of the real estate market, such as Poblenou. Its urban fabric, with large spaces, lower rents than other neighbourhoods in the city, and its central location, attracted various artists' workshops (El Periodico 2006).

There is no comparable data for the period prior to 1992. Nevertheless, by 1992, spaces in the Sant Martí district (where Poblenou is located) were an average of 21.4 per cent cheaper for sale, and 17 per cent cheaper for rent, than in the rest of the city. After the 1992 Olympics, Barcelona entered a period of economic crisis. This crisis affected housing and commercial real estate values negatively; they did not rise, and in some cases prices fell in the following years. The turning point in real estate values came in the year 2000, when real estate prices of commercial premises in Sant Martí district rose above the average prices of the city as a whole for the first time. The average price of commercial premises in Barcelona increased by 115 per cent between 2000 and 2007. In the same period, rental prices increased, on average, by 57 per cent in Barcelona, but by 95 per cent in Ciutat Vella and 54 per cent in Sant Martí. Over a longer period of time, the prices of commercial spaces in the Sant Martí district between 1992 and 2007 increased from $874 \cdot \mathrm{m}^{2}$ to $1,615 \cdot \mathrm{m}^{2}$.

A study carried out by the Catalonia Association of Visual Artists (AAVC) shows that twenty-three workshops accounting for 142 artists and 12,770 square meters had closed down in Poblenou by 2006. In particular, the study highlights the closing of two spaces of historical significance located in the 1990s: El Submarí and Can Font, which had hosted 30 and 10 artists, respectively.

By the end of 2006, the disappearance of the workshops in Poblenou attracted media attention, with the closing of La Escocesa, a creative space located in a former textile factory. On November 20th, 2006, around 50 artists, including a theatre group, a music ensemble, a circus and a group of art creators located in a space of about 5,000 square meters were evicted by the police, which was carrying out a court ruling. These artists had established themselves in the building in 1999, when the rent was low, and the building was considered obsolete. However, by 2006, the old factory had been bought by a real estate developer with a plan to redevelop a group of lofts, offices and cultural spaces.

La Escocesa moved to another historical factory, Can Ricart, in protest against this eviction. Eventually, the fight for Can Ricart would epitomize the complex urban and social implications of the redevelopment process in Poblenou led by the City 
Council. A coalition of displaced artists, small family businesses, trade union leaders, neighbourhood associations and some university communities organized a protest group to generate media attention in relation to what they believed were the negative artistic, social, economic and architectonic implications of the 22@Barcelona project (Figure 2).

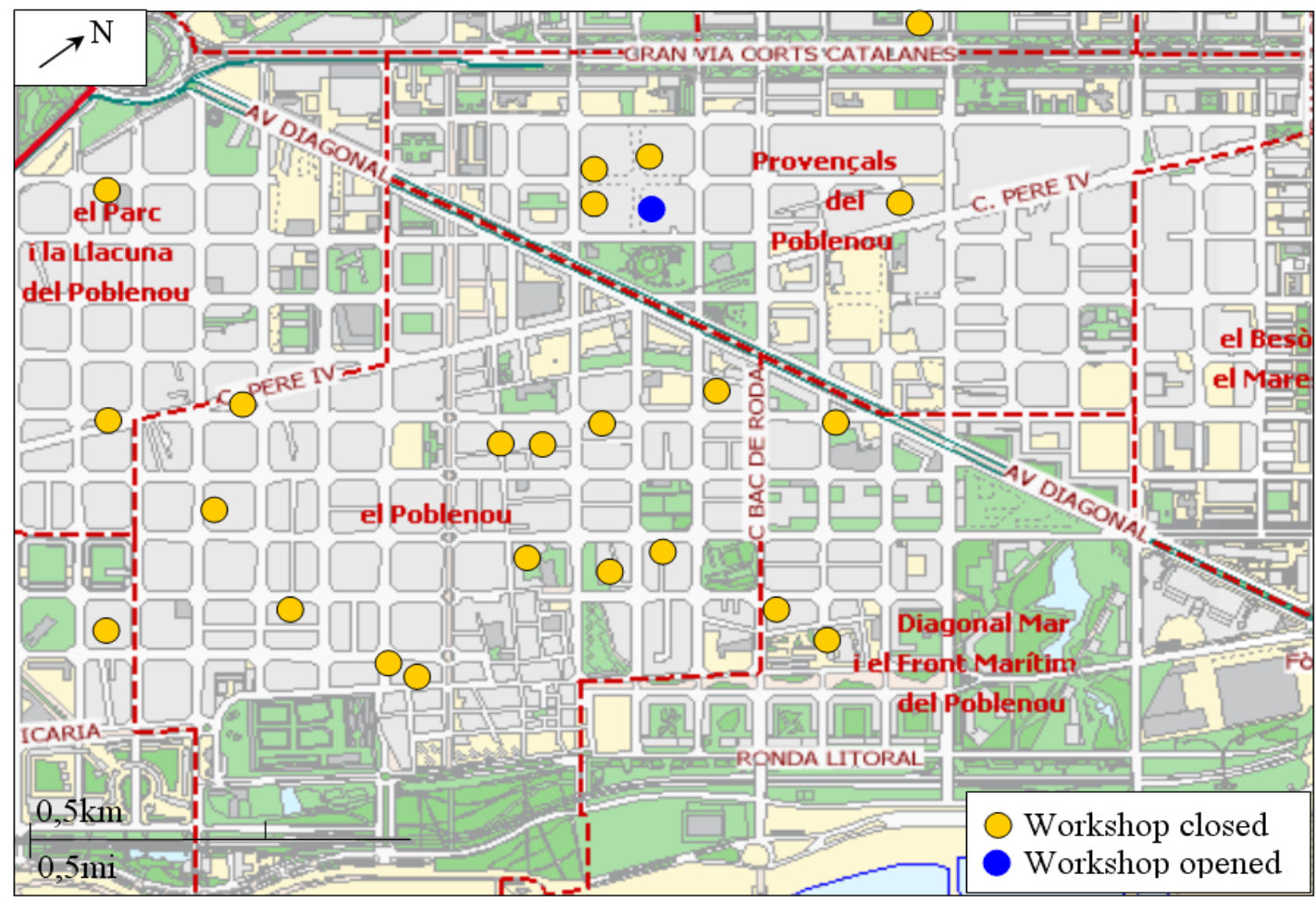

Figure 2: Evolution of artists’ Workshops. Poblenou’s urban grid follows Cerdà's blocks (Pallares-Barbera et al. 2011). Source: Adapted from El Periódico, 14/03/2007.

\section{The Hangar Centre in Can Ricart Factory}

Can Ricart is an example of contested urban redevelopment space in Barcelona due to the confrontation that its regeneration has created between various political, academic and social actors (Casellas 2007, Clarós 2007, Martí-Costa and Bonet-Martí 2008). Can Ricart has been identified by university professors and community groups as a complex with architectural value; it was formerly a textile factory, built in the 19th century under the direction of the architects Josep Oriol Bernadet and Josep Fontseré Mestres (Tatjer et al. 2005). The initial plans of the developer involved the demolition of the entire complex. After a long period of opposition from community groups, by 2009 the final plans approved by the City Council protected a small section including a clock tower and the building where the Hangar artists are located.

The Can Ricart factory had become obsolete in the 1970s, and the owner had eventually rented spaces to various groups of small companies and artists. As a result, the factory was converted and used as warehouse, workshops and artist spaces, all which rented at a low cost. In 2000, with the implementation of the 22@Barcelona plan, the Marquis of Santa Isabel, the owner of Can Ricart, realized the potential real estate value of his property and presented a redevelopment plan that included a hotel and office spaces. The plan involved the demolition of the entire building complex and the 
displacement of 34 small companies and several artistic groups. As a consequence of the new redevelopment plan, and despite community group's opposition, a total of 250 jobs had been displaced or lost by 2007. Among those displaced was the group of artists Nau 21. Of a total of 24 companies for which we have collected information, 15 companies relocated outside Poblenou and 6 companies disappeared. Only 3 firms have relocated in the neighbourhood. The only one left in Can Ricart was Hangar (Dot 2009).

The Hangar Centre is an artistic production association created in 1997 by the Catalan Association of Visual Artists, and is located in Can Ricart. Its premises cover 1,800 square meters and its main function is to "provide support for new generations of artists, whatever the nature of their work and the tools they use to produce it" (http://www.artfactories.net). The centre provides three different spaces. First, there are 15 rental studios at very affordable rates (110 to $250 € /$ month) for a maximum of two years in residence, for young artists (between 25 to 35 years old). The artists are selected by a committee and various artistic specialties and nationalities may apply. Second, the Hangar Centre provides access to space with equipment, programs and qualified technicians specializing in creation using digital technologies. Third, it offers a forum space for international exchange between artists.

The Hangar Centre was able to survive because it receives financial support from public institutions including the Government of Catalonia (La Generalitat), the City Council, through Barcelona's Culture Institute (Icub), the Spanish government, through the Ministry of Culture, and the Barcelona Provincial Council (Diputació de Barcelona). It also receives some contributions from private corporations such as local banks. Its annual budget is around $450,000 €$, and more than 50 per cent is subsidized by the Catalan government (Hangar 2008).

Initially, Hangar chose the Can Ricart factory because the owner offered the facility to the artists' association in an attempt to replicate the Lower East Manhattan experience. Ten years later, despite the attempts at displacement, and because of pressure from artists, the local community, university groups and public institutions, the City Council finally agreed that the artists should stay and backed the protection of parts of the old factory and forced the owner to reformulate his real estate strategy. However, the final solution did not please the local community and artists' groups, which see Can Ricart as a symbol of the citizens' defeat by a boosteristic City Council which is isolated from grassroots movements.

\section{Concluding Remarks}

The concept of creativity and artists is quite vague and many different artistic groups and individual activities could be included or excluded from that classification. Jordi Marti, the head of the City Council's Cultural Department, said in 2007 that "the capacity of Hangar to generate initiatives and proposals beyond artistic production, the idea of a laboratory, its public vocation and involvement with its environment, all make it a point of reference” (El País 28-06-2007). However, looking at the experience of artists in Poblenou and the ambiguities of the City Council with Can Ricart, the Hangar experience, so far, seems to be more of an exception than a general rule.

The 22@Barcelona project has led to contradictory urban, economic and social consequences for individuals and firms traditionally located in Poblenou. Among these are the small groups of artists, which have been negatively affected by the renewal plans directed by the public sector. Furthermore, the relationship between the City Council and groups of artists in Barcelona has been quite contradictory. While the 
implementation of the 22@Barcelona project displaced many artists from the area, in 2006 the City Council's Cultural Strategic Plan presented ten new projects for restoring old factories or optimizing new spaces as venues for artists' activities. Eight locations had been identified by 2008. Of these, four were located in the Sant Martí district. In La Escocesa factory, an old complex in Poblenou, the City Council has plans to restore two buildings as creative spaces. This covers more than 1,000 square meters. The budget of the City Council for the ten projects amounts to 23.5 million $€$ (El Periódico 27/10/2007). Additionally, a new planned expansion approved for Can Ricart will add 810 square meters of new spaces for artistic creativity next to the existing Hangar centre. With the expansion of the old complex, Can Ricart would preserve few of the central architectonic structures of the old factory, which have been defended by community based groups and local intellectuals.

Although the City Council has portrayed the decision on Can Ricart as an example of its interest in maintaining emblematic buildings and supporting artists, community groups have criticized the decision as insufficient. The spatial, social and economic structure of Poblenou is undergoing a radical process of change. As a result, even though new groups of artists may benefit from upgraded space in the near future, the small, alternative and low-budget groups that found cheap locations in Poblenou in the 1980s and 1990s have been unable to remain in the neighbourhood and have been significantly displaced. It can therefore be concluded that the difficulties for low budget artists installed in Poblenou in remaining in the neighbourhood increased dramatically as the implementation of the 22@Barcelona project began. This difficulty was the result of a potential rent-gap generated by the new redevelopment plans. Nevertheless, in the displacement of artists, a key role was also played by the restrictive new zoning regulations generated by the public sector and the aspects of the public project linked to the fostering of new high value economic activities.

\section{References}

Ajuntament de Barcelona 2008. Districtes. Available online at: www.bcn.es [accessed: 14 June 2010].

Ajuntament de Barcelona 2007. Statistical data. Available online at: www.bcn.es/estadistica [accessed: 14 June 2010].

Ajuntament de Barcelona 2000. MPGM (Modification of the PGM (General Municipal Plan) for the Renovation of the Industrial Areas of Poblenou). Available online at: www.bcn.es/22@bcn/engl/planesyproyectos/plan22@/index.html [accessed 14 June 2010].

Artfactories. 2008 Hangar Barcelona. Available online at: www.artfactories.net/ article.php3?id_article=138 [accessed: 14 June 2010].

Associació d'Artistes Visuals de Catalunya 2008. Estudi Sobre els Espais de Creació a Barcelona. Available online at: www.aavc.net [accessed: 14 June 2010].

Atkinson, R. 2000. Measuring gentrification and displacement in Greater London. Urban Studies, 37(1), 149-165.

Beauregard, R. 1986. The chaos and complexity of gentrification, in Gentrification of the City, edited by N. Smith, and P. Williams. Boston: Allen \& Unwin, 35-55.

Bianchini, F. and Parkinson, M. (eds.) 1993. Cultural Policy and Urban Regeneration: The West European Experience. New York: Manchester University Press. 
Casellas, A. 2007. Gobernabilidad, participación ciudadana y crecimiento económico. Adaptaciones locales a estrategias globales, Scripta Nova XI (243). Available online at:www.ub.es/geocrit/sn/sn-243.htm [accessed: 14 June 2010].

Casellas, A. 2009. Barcelona's urban landscape: The historical making of a tourist product. Journal of Urban History, 35(6), 815-832.

Casellas, A. and Pallares-Barbera, M. 2009. Public sector intervention in embodying new economy in inner urban areas: The Barcelona experience. Urban Studies, 46(5), 1137-1156.

Clarós, S. 2007. De la Ciutat dels Prodigis a la Barcelona social. Biblio 3W, XII (751). Available online at: www.ub.es/geocrit/b3w-751.htm [accessed: 14 June 2010].

Dot, E. 2009. L'Espai Econòmic del Poblenou al Segle Vint-i-u: Nous Contextos, Noves Activitats. Unpublished Master Thesis. Geography Department, Universitat Autonoma de Barcelona.

El Periodico. 2007. Bcn Invertirá 23.5 Millones en las Diez Fábricas de Creación Cultural. 27/10/2007.

El Periodico. 2007. Arte en Miniatura. 14/03/2007.

El Periodico. 2006. La Presió Inmobiliaria Deixa el Poblenou Sense Tallers de Artistes. 4/17/2006.

El País. 2007. Hangar, de Prototipo a Model. Suplement Cuadern. 28/06/2007.

Krueger, R. and Gibbs, D. 2007. The Sustainable Development Paradox. New York: The Guilford Press.

Hangar 2008. Hangar.org. Available online at: www. hangar.org [accessed: 14 June 2010].

Hayward, D. 2006. Creative Clusters: A Critical Examination of the Processes Behind and Implications of the Emergence of a Creative Cluster in Shoreditch, London. Unpublished Master Thesis. Geography Department, University of Portsmouth.

Ley, D. 1987. Reply: the rent-gap revisited. Annals of the Association of the American Geographers, 77, 465-468.

Ley, D. 1994. Gentrification and the politics of the new middle class. Environment and Planning D: Society and Space, 12, 53-74.

Lloyd, R. 2006. Neo-Bohemia. London: Routledge.

Maragall, P. 1988. Urbanisme a Barcelona, Plans Cap el 92. Barcelona: Ajuntament de Barcelona, Area de Urbanisme i Obres Públiques.

Martí-Costa, M. and Bonet-Martí, J. 2008. Planning from below in Barcelona, in Whose Urban Renaissance? An International Comparison of Urban Regeneration Strategies, edited by L. Porter and K. Show. New York: Routledge, 118-128.

Martorell, J., Bohigas, O., Mackay, D. and Puigdomenech, A. 1992. La Villa Olímpica: Arquitectura, Parques, Puerto Deportivo. Barcelona: Editorial Gustavo Gili, S.A.

Marrero-Guillamón, I. 2000. Del Manchester Catalán al Soho Barcelonés? La Renovación del Barrio del Poblenou en Barcelona y la Cuestión de la Vivienda, Scripta Nova II (146). Available online at: http://www.ub.es/geocrit/sn/sn146(137).htm [accessed: 14 June 2010].

Pallares-Barbera, M., Badia, A., Duch, J. 2011. Cerdà and Barcelona: The need for a new city and service provision. Urbani izziv, volume 22, no. 2, pp.: 122-136. http://urbani-izziv.uirs.si/en/Urbaniizziv/tabid/95/Default.aspx. DOI: 10.5379/urbani-izziv-en-2011-22-02-005. 
Smith, N. 1986. Gentrification, the frontier and the restructuring of urban space, in N. Smith and P. Williams, Gentrification of the City, Boston: Allen \& Unwin.

Smith, N. 1987. Gentrification and the rent-gap. Annals of the Association of American Geographers, 77(3), 462-465.

Smith, N. 1996. The New Urban Frontier: Gentrification and the Revanchist City, London: Routledge.

Tatjer, M., Urbiola, M. and Grup de Patrimoni Industrial del Fòrum Ribera Besòs 2005. Can Ricart. Estudi Patrimonial (Sintesi), Biblio 3W, 598:X. Available online at: http://www.ub.es/geocrit/b3w-598.htm [accessed: 14 June 2010].

Tironi, M. 2009. Urbanismo creativo (en la ciudad performativa). Espacios y pràcticas de la escena de música experimental en Santiago, Chile. Tesis Doctoral. Escola Tècnica Superior d'Arquitectura de Barcelona, Departament d'Urbanisme I Ordenació, Universitat Politècinica de Catalunya.

Zukin, S. 1982. Loft Living. Rutgers University Press: New Jersey.

22@Barcelona 2008. The 22@BarcelonaProject. Available online at: http://www.bcn.es/22@bcn/pdf/22@_state_execution.pdf [accessed: 14 June 2010]. 